\title{
HUBUNGAN PENGETAHUAN DENGAN SIKAP PERAWAT DALAM MEMBERIKAN EDUKASI TERAPI KOMPLEMENTER PADA PASIEN STROKE DI RUMAH SAKIT UMUM KABUPATEN TANGERANG
}

\author{
${ }^{1}$ Betty, ${ }^{2}$ Dila Kamilah Amalia \\ Program Studi S1 Keperawatan STIKes Widya Dharma Husada Tangerang \\ ${ }^{1}$ Email: betchy_cew@ymail.com
}

\begin{abstract}
ABSTRAK
Latar Belakang Stroke merupakan penyakit terbanyak ketiga setelah penyakit jantung dan kanker, serta merupakan penyakit penyebab kecacatan tertinggi di dunia. angka kematian penderita stroke di Amerika setiap tahunnya adalah 50 - 100 dari 100.000 orang penderita. Hasil Riskesdas Kementerian Kesehatan Republik Indonesia tahun 2018 terjadi peningkatan prevalensi stroke dari tahun 2013 hingga 2018 yaitu 7 per mil menjadi 10,9 per mil. Stroke dapat menyebabkan gangguan yang komplek pada tubuh dan konsekuensi negatif bagi pasien yang bertahan hidup. Penanganan pasien dengan gangguan neurologi seperti stroke tidak hanya terfokus pada pengobatan medis kedokteran atau konvensional, namun sudah berkembang pada pengobatan alternatif komplementer/complementary alternative medicine $(C A M)$. Perawat dalam menjalankan tugasnya di tuntut untuk memiliki pengetahuan dan keterampilan yang kompeten, Keikut sertaan perawat dalam mengaplikasikan terapi alternatif kepada pasien merupakan suatu bentuk sikap perawat dalam pandangannya terhadap terapi alternatif komplementer. Tujuan Penelitian ini adalah untuk mengidentifikasi hubungan pengetahuan dengan sikap perawat dalam memberikan edukasi terapi komplementer pada pasien stroke di Rumah Sakit Umum Kabupaten Tangerang. Metode Penelitian ini menggunakan metode penelitian cross sectional dan metode sampling yang digunakan adalah total sampling. Sampel dalam penelitian ini adalah 60 perawat di ruang perawatan umum Rumah Sakit Umum Kabupaten Tangerang. Pengambilan data menggunakan data primer dengan kuesioner pengetahuan dan sikap. Menggunakan uji statistic korelasi dengan analis Spearman Rho. Hasil Penelitian di perolah hasil adanya hubungan pengetahuan dengan sikap perawat dalam memberikan edukasi terapi komplementer pada pasien stroke di Rumah Sakit Umum Kabupaten Tangerang. Hasil uji statistik di peroleh hasil $p$-value $=0,000<0,05$.Saran diharapkan perawat mampu berkontribusi dan menyikapi terapi komplementer ini dengan positif serta dapat mengintegrasikannya kedalam pelayanan keperawatan.
\end{abstract}

Kata Kunci : Stroke, Terapi Komplementer, Perawat

\section{RELATIONSHIP BETWEEN KNOWLEDGE WITH ATTITUDE OF NURSES TO GIVE COMPLEMENTARY ALTERNATIVE MEDICINE EDUCATION TO STROKE PATIENTS IN TANGERANG DISTRICT GENERAL HOSPITAL}

\begin{abstract}
ABSTRACK
Background Stoke is the most common disease after cancer and heart diseases, also is the highest disease causing disabillty in the world dead rate for stroke patients in America every years is 50-100 from 100.000 suffers. Riskesdas Kementrian Kesehatan Republik Indonesia result in 2018 an increase in prevalence from 2013 till in 2018 is 7 per mile occars 10,9 per mile. Stroke can cause complex disorder of the body and negative conseavences for patient who survive. Treatment of patients in neurological disorder such as stroke nor only focused in medical medicine or convencional, but it has developed in complementary alternative medicine (CAM). Nurses in out their duties are required to have knowledge and skill that competenst, the participation of nurses in applying of complementary alternative medicine for patient is a from of nurses attitude in his view of complementary alternative medicine. Research purpose to identification relationship between knowledge and nurses' attitudes to giving complementary alternative medicine education for stroke patients in general hospital district of kabupaten tangerang. Research metods using primary data with a knowledge questionnaire and attitude, using the statistical test with spearman rho analysis. Research result obtained the result of relationshipbetween knowledge and attitudes nurses to giving complementary alternative medicine education for stroke patients in general hospital district of kabupaten Tangerang. Statictical result is obtained the result p-value $=0,000<0,05$. Suggestions nurses's are expected to be able contribute and respond this complementary alternative medicine with positive and can integrate into nursing services.
\end{abstract}

Keywords :Stroke, Complementary Alternative Medicine, Nurses 


\section{PENDAHULUAN}

Stroke merupakan penyakit terbanyak ketiga setelah penyakit jantung dan kanker, serta merupakan penyakit penyebab kecacatan tertinggi di dunia. Menurut American Heart Assocation (AHA) angka kemation penderita stroke di Amerika setiap tahunnya adalah 50 100 dari 100.000 orang penderita. Di negara - negara ASEAN penyakit stoke juga merupakan masalah kesehatan utama yang menyebabkan kematian. Dari data South East Asian Medical Information Centre (SEAMIC) diketahui bahwa angka kematian stroke terbesar terjadi di Indonesia yang diikuti secara berurutan oleh Filipina, Singapura, Brunei, Malaysia dan Thailand (Dinata, Safrita dan Sastri, 2013). Hasil Riskesdas Kementrian Kesehatan Republik Indonesia tahun 2018 terjadi peningkatan prevalensi stroke dari tahun 2013 hingga 2018 yaitu 7 per mil menjadi 10,9 per mil. Prevalensi tertinggi terjadi di daerah Kalimantan Timur (14,7 per mil), Yogyakarta (14,5 per mil), Sulawesi Utara (14 per mil) dan Banten (10,9 per mil).

Stroke dapat menyebabkan gangguan yang komplek pada tubuh dan konsekuensi negatif bagi pasien yang bertahan hidup. Stroke menyebabkan kelumpuhan, kekuatan pikiran berkurang, hilangnya perasaan, kesulitan - kesulitan praktis, ketidakmampuan fungsional, perubahan kepribadian, perubahan emosional, epilepsi, dan gangguan komunikasi, stroke akan membawa pengaruh terhadap semua aspek kehidupan seseorang yang mengalaminya baik dari aspek personal, sosial, vokasional dan fisik. Penderita stroke akan mengalami ketergantungan pada orang lain khususnya keluarga dan menyebabkan gangguan relasi sosial (Zahro dkk, 2014). Perawatan pasien stroke tidak hanya terfokus pada pengobatan medis kedokteran atau konvensional, namun sudah berkembang pada pengobatan alternatif komplementer/ complementary alternative medicine (CAM).

Penelitian yang dilakukan oleh Wells et al (2010) dalam Husna \& Setiawan, (2016) menjelaskan jenis terapi alternatif komplementer yang sering digunakan oleh pasien stroke adalah mind body therapies jenis terapi yang digunakan adalah yoga, meditasi, hypnosis, dan deep exercise. Biologicalbased therapy jenis terapi nya breathing, herbal, massage dan chiropractic. Alternative medical system jenis terapi nya 
pengetahuan dan pengalaman perawat terkait terapi alternatif komplementer masih terbatas, oleh karena itu dibutuhkan suatu upaya untuk terus mengikuti perkembangan terapi alternatif dan mengikuti pelatihan yang resmi, dan bersertifikat untuk meningkatkan kemampuan perawat dalam memberikan terapi alternatif pada pasiennya baik berupa edukasi, maupun aplikasi langsung pada pasien.

Berdasarkan studi pendahuluan yang dilakukan di Rumah Sakit Umum Kabupaten Tangerang 7 dari 10 perawat memiliki pengetahuan yang kurang terhadap terapi komplementer dan 2 orang memiliki sikap yang sangat setuju untuk memberikan edukasi terapi komplementer, 5 orang setuju dan 3 orang tidak setuju untuk memberikan edukasi terapi komplementer pada pasien stroke, dan belum ada perawat yang melakukan perilaku pemberian edukasi terapi komplementer pada pasien stroke. Berdasarkan fenomena di atas peneliti tertarik untuk melakukan penelitian dengan judul "Hubungan Pengetahuan Dengan Sikap Perawat Dalam Memberikan Edukasi Terapi Komplementer Pada Pasien Stroke Di
Rumah Sakit Umum Kabupaten Tangerang“6.

\section{METODE PENELITIAN}

Penelitian ini merupakan penelitian Deskriptif Analitik dengan rancangan penelitian menggunakan desain penelitian Cross Sectional.

Penelitian ini dilakukan di Rumah Sakit Umum Kabupaten Tangerang pada tanggal 15 - 20 Mei 2019. Partisipan yang dilibatkan dalam penelitian ini adalah 60 orang perawat di ruang perawatan umum RSU Kabupaten Tangerang. Tehnik pemilihan partispian dalam penelitian ini menggunakan total sampling. Metode pengumpulan data dalam penelitian menggunakan kuesioner yang berisi pertanyaan mengenai pengetahuan dan sikap perawat dalam memberikan edukasi terapi komplementer pada pasien stroke.

\section{HASIL PENELITIAN}

Partisipan dalam penelitian ini berjumlah 60 orang perawat yang bertugas di ruang perawatan umum RSU Kabupaten Tangerang. Karakteristik partisipan meliputi usia, jenis kelamin dan pendidikan. 
Tabel 1. Karakteristik Responden

Berdasarkan Umur

\begin{tabular}{cccll}
\hline Umur & Frekuensi & Mean & Median & $\begin{array}{l}\text { Modu } \\
\text { s }\end{array}$ \\
\hline $17-25$ & 19 & 28,77 & 28,00 & 28 \\
$26-35$ & 36 & & & \\
$36-45$ & 3 & & & \\
$46-55$ & 1 & & & \\
Total & 60 & & & \\
\hline
\end{tabular}

Berdasarkan tabel 5.1 rata - rata responden berada dalam usia 28 tahun sebanyak 36 perawat, hal ini menunjukan bahwa rata - rata perawat ada di usia produktifnya yaitu di usia 28 tahun.

Tabel 2. Karakteristik Responden Berdasarkan Jenis Kelamin

No Jenis Kelamin $\mathrm{N} \quad(\%)$

\begin{tabular}{llll}
\hline 1 & Laki-laki & 20 & $33,3 \%$ \\
2 & Perempuan & 40 & $66,7 \%$ \\
\hline & Total & 60 & $100 \%$ \\
\hline
\end{tabular}

Berdasarkan tabel 5.2 dapat dilihat bahwa hampir $66,7 \%$ responden berjenis kelamin perempuan sebanyak 40 perawat. Karena memang hampir sebagian yang berprofesi menjadi perawat adalah yang berjenis kelamin perempuan.

Tabel 3. Karakteristik Responden Berdasarkan Pendidikan

\begin{tabular}{llll}
\hline No & & N & $(\%)$ \\
& Pendidikan & & \\
\hline 1 & D3 Keperawatan & 32 & $53,3 \%$ \\
2 & S1 Ners & 28 & $46,7 \%$ \\
\hline & Total & 60 & $100 \%$ \\
\hline
\end{tabular}

Berdasarkan tabel 5.3 dapat dilihat bahwa 32 responden memilki pendidikan yaitu D3 Keperawatan sebanyak 32 perawat

Tabel 4. Karakteristik Responden Berdasarkan Pengetahuan

\begin{tabular}{llll}
\hline No & N & $(\%)$ \\
& $\begin{array}{l}\text { Pengetahuan } \\
\text { Perawat }\end{array}$ & & \\
\hline 1 & Baik & 47 & $78,3 \%$ \\
2 & Kurang & 13 & $21,7 \%$ \\
\hline & Total & 60 & $100 \%$ \\
\hline
\end{tabular}

Berdasarkan tabel 5.4 diperoleh distribusi frekuensi responden ssebanyak 47 (78,3\%) dengan tingkat pengetahuan baik dan sebagian kecil dari responden dengan tingkat pengetahuan kurang $(21,7 \%)$.

Tabel 5. Karakteristik Responden Berdasarkan Sikap

\begin{tabular}{llll}
\hline No & Sikap Perawat & N & $(\%)$ \\
& & \\
\hline 1 & Positif & 50 & $83,3 \%$ \\
2 & Negatif & 10 & $16,7 \%$ \\
\hline & Total & 60 & $100 \%$ \\
\hline
\end{tabular}

Berdasarkan tabel 5.5 diperoleh distribusi frekuensi hampir dari seluruh responden sebanyak 50 orang perawat dengan sikap positif sebanyak $(83,3 \%)$ dan sebagian kecil dari responden dengan sikap negatif 10 $(16,7 \%)$. 
Tabel 6. Crosstab tabel silang pengetahuan perawat dengan sikap perawat

\begin{tabular}{|c|c|c|c|c|}
\hline & & \multicolumn{2}{|c|}{ sikap perawat } & Total \\
\hline & & positif & legatif & \\
\hline pengetahuan & baik & 47 & 0 & 47 \\
\hline perawat & kurang & 3 & 10 & 13 \\
\hline Total & & 50 & 10 & 60 \\
\hline
\end{tabular}

Hasil dari tabel crosstab di dapatkan kesimpulan jika pengetahuan perawat tentang terapi komplementer baik maka sikap dalam memberikan edukasi adalah positif dan jika pengetahuan perawat tentang terapi komplementer kurang maka sikap dalam memberikan edukasi adalah negatif.

Tabel 7. Analisis Hubungan Pengetahuan Dengan Sikap

\begin{tabular}{lcccc}
\hline Variabel & Mean & SD & $\begin{array}{l}\text { Spearma } \\
n \text { 's } \\
\text { Nilai } \\
\text { Korelasi }\end{array}$ & Sho \\
& & \multicolumn{3}{c}{ Sig } \\
$\begin{array}{l}\text { Pengetahu } \\
\text { an }\end{array}$ & 1,22 & .415 & .850 & .000 \\
\hline Sikap & 1,17 & .376 & & \\
\hline
\end{tabular}

Diperoleh nilai signifikan p-value 0,000. Sehingga keputusan uji adalah Ho ditolak atau Ha diterima artinya ada nya Hubungan Pengetahuan Dengan Sikap Perawat Dalam Memberikan Edukasi Terapi Komplementer Pada Pasien Stroke Di RSU Kabupaten Tangerang dengan nilai korelasi spearman rho sebesar 0,850 yang menunjukan bahwa arah korelasi positif yang berarti hubungan sangat kuat, jika pengetahuan nya baik maka sikap nya pun semakin positif.

\section{PEMBAHASAN}

Dari hasil penelitian yang telah dilakukan di RSU Kabupaten Tangerang tahun 2019 didapatkan hasil bahwa hampir dari seluruh perawat sebanyak 78,3\% mempunyai pengetahuan tentang terapi komplementer dalam tingkatan baik. Pengetahuan merupakan domain yang sangat penting dalam membentuk tindakan seseorang (Overt behavior). Salah satu faktor yang mempengaruhi pengetahuan yaitu usia, semakin bertambah nya usia seseorang diasumsikan bertambah pula pengetahuannya seiring dengan bertambahnya pengalaman dan kematangan diri. Hasil ini sesuai dengan penelitian yang dilakukan Ali (2017) tentang Hubungan Tingkat Pengetahuan Dan Sikap Ibu Dengan Penggunaan Pengobatan Alternatif dan Komplementer Selama Kehamilan di RSIA Sakina Idaman Sleman dengan hasil uji chi square dengan tingkat kesalahan 5\% di dapatkan nilai OR nya 2,721 dengan $\mathrm{p}=0,041$. Sehingga dapat disimpulkan bahwa adanya hubungan.

Sejalan pula dengan hasil penelitian yang dilakukan oleh Rojas Coley (2009) dengan judul Complementary alternative mediciene: 
oncology nurses's knowledge andattitude, penelitian berjenis studi dengan pendekatan cross sectional ini menunjukan hasil sebanyak $70 \%$ perawat memiliki pengetahuan yang baik. Menurut peneliti data yang menunjukan bahwa sebagain besar responden memiliki pengetahuan baik, hal ini disebabkan karena responden rata - rata berusia 28 tahun, dimana usia 28 tahun adalah usia produktif dan dapat menerima informasi apapun dari berbagai sumber dengan baik. Usia mempengaruhi pengetahuan seseorang, sesuatu yang pernah dialami di usia muda seseorang akan menambah pengetahuan orang tersebut dan dapat menjadi sumber pengetahuan yang bersifat informal.

Dari hasil penelitian yang telah dilakukan di RSU Kabupaten Tangerang tahun 2019 di dapatkan hasil hampir sebagian perawat yaitu $83,3 \%$ mempunyai sikap positif. Sikap belum merupakan suatu tindakan atau aktifitas, akan tetapi adalah merupakan predisposisi tindakan atau perilaku. Salah satu faktor yang mempengaruhi sikap yaitu pengalaman pribadi dan orang lain yang dianggap penting. Sejalan dengan hasil penelitian yang dilakukan oleh Setyaningsih(2012) tentang Hubungan Anatara Persepsi Dengan Sikap Masyarakat Terhadap Pengobatan Komplementer Di Kecamatan
Grogol Kabupaten Sukoharjo. Jenis penelitian studi deskriptif dengan pendekatan cross sectional. Hasil penelitian menunjukan responden pada sikap yang positif adalah 47\%. Hasil penelitian ini pula sesuai dengan hasil penelitian yang dilakukan Balouchi (2018) tentang Knowledge, attituted and use of complementary and alternative medicine among nurses. Jenis penelitian ini adalah dengan studi deskriptif dan metode penelitian wawancara. Hasil penelitian ini menunjukan $51,6 \%$ perawat memiliki sikap positif. Menurut peneliti dapat disimpulkan bahwa sikap perawat sudah mampu untuk mengaplikasikan suatu respon terhadap tindakan untuk memberikan edukasi terapi komplementer pada pasien stroke. Hal ini bisa disebakan karena rata - rata usia responden yang muda dan juga di pengaruhi oleh tingkat pendidikan yang dapat membentuk sikap seseorang.

Pada hasil penelitian ini didapatkan bahwa responden yang memiliki pengetahuan baik sebanyak 47 perawat dan dengan sikap dalam kategorik positif sebanyak 50 perawat. Hasil uji spearman rho diperoleh hasil signifikan pvalue 0,00 sehingga keputusan uji adalah Ho ditolak atau Ha diterima artinya adanya Hubungan Pengetahuan Dengan Sikap Perawat Dalam Memberikan Edukasi 
Terapi Komplementer Pada Pasien Stroke

Di RSU Kabupaten Tangerang dengan nilai korelasi 0.850 yang menunjukan arah hubungan nya kuat positif, maka semakin baik pengetahuan perawat tentang terapi komplementer maka akan semakin positif sikap nya dalam memberikan edukasi terapi komplementer. Menurut peneliti, pengetahuan tentang terapi komplementer yang baik dipastikan memilki sikap postif dalam memberikan edukasi terapi komplementer pada pasien stroke dan sikap perawat yang menunjukan hasil positif ini termasuk kedalam tingkatan sikap yaitu, menerima.

\section{KESIMPULAN}

Kesimpulan dari hubungan pengetahuan dan sikap perawat dalam memberikan edukasi terapi komplementer sebanyak 47 dari 60 perawat memiliki pengetahuan yang baik, sebanyak 50 dari 60 perawat memiliki sikap yang positif dan hasil nya ada hubungan antara pengetahuan dengan sikap perawat dalam memberikan edukasi terapi komplementer pada pasien stroke di RSU Kabupaten Tangerang, dengan p-value $0,00<0,05$

\section{DAFTAR PUSTAKA}

American Heart Association (AHA). 2015. Let's Talk About Stroke.
Ali, Rizky Nikmatul Husna. 2017. Hubungan Tingkat Pengetahuan Dan Sikap Ibu Dengan Penggunaan Pengobatan Alternatif Dan Komplementer Selama Kehamilan Di Rsia Sakina Idaman Sleman. Yogyakarta

Balouchi, A., Mahmoudirad, G. dan Hastings tolsma, M. 2018. Complementary Therapies in Clinical Practice Knowledge attitude and use of complementary and alternative medicine among nurses: A systematic review', 146-157.

Dinata, C. A., Safrita, Y. dan Sastri, S. 2013. Gambaran faktor Risiko dan tipe Stroke pada Pasien Rawat Inap.Padang : Jurnal Kesehatan Andalas, 57-61.

Husna Elfira, Setiawan, T. R. 2016. Pengalaman Perawat Dalam Menerapkan Terapi Complementary Alternative Medicine Pada Pasien Stroke Di Sumatera Barat', Ners Jurnal Keperawatan, 12(1), Pp. 15-23.

Kementerian Kesehatan Republik Indonesia . 2018. Hasil Utama Riskesdas 2018'. Jakarta

Lindquist, R. 2014.Complementary / Alternative Therapies In Nursing. Seventh Edition. USA: Springer Publishing Company

Mahan, Tracy. 2012.Complementary and alternative medicine : nurses' attitudes and knowledge.

Natale, Nicol. 2018. 6 Complementary and Alternative Therapies for Stroke. Medical Review 
Purboyekti, S. 2017. Gambaran persepsi masyarakat terhadap pengobatan komplementer dan alternatif di wilayah kelurahan pondok benda rw 013 pamulang 2 '.

Coley, M Teresa Rojas. 2009.Complementary and alternative medicine : oncology nurses' knowledge and attitudes.

Setyaningsih, Y. 2012.Hubungan Anara Persepsi Denga Sikap Masyarakat Terhadap Pengobatan Komplementer Di Kecamtan Grogol Kabupaten Sukoharjo. Universitas Mahammadiyah Surakarta.

Widyatuti. 2017. Terapi Komplementer Dalam Keperawatan.Jurnal Keperawatan Indonesia, 12(01), Pp. 53-57. Doi: 10.7454/Jki.V12i1.200.

Zahro, Khirnik Fatimatuz, Pudjo Wahjudi, A. R. 2014. Gambaran Pemanfaatan Pengobatan Alternatif Pada Penderita Stroke di Kabupaten Jember (The Utilization of Alternative Medicine to Stroke Patients in Jember ), Jurnal Ilmiah Hasil Penelitian Mahasiswa. Hal 1-7. 
Edudharma Journal, Vol 3 No 2, September 2019, page 56-63

59 | P a g e 
Edudharma Journal, Vol 3 No 2, September 2019, page 56-63

$60 \mid$ P a g e 
Edudharma Journal, Vol 3 No 2, September 2019, page 57- 